\title{
A test of naturalness indicator values to evaluate success in grassland restoration
}

\author{
P. Sengl ${ }^{1}$, M. Magnes ${ }^{2}$, L. Erdős ${ }^{3}$ and C. Berg ${ }^{2}$ \\ ${ }^{1}$ Civil Engineering Office Kofler Umweltmanagement, Austria. Corresponding author. E-mail: nwsephi@gmx.at \\ ${ }^{2}$ Institute of Plant Sciences, University of Graz, Austria \\ ${ }^{3}$ Institute of Ecology and Botany, MTA Centre for Ecological Research, Vácrátót, Hungary
}

Keywords: Compensation measures; Hay transfer; Passive restoration; Seeding; Sod transplantation.

\begin{abstract}
How should the somewhat vague term of restoration success be measured? This is a critical question rooted in European law, where in fact the creation of proper replacement habitats is a prerequisite for permitting projects that trigger a loss of species or habitats. Previous studies have used indices that relied on a comparison to reference sites, for example the number of a predefined pool of target species or compositional similarity. However, since restoration sites have rarely the same biotic and abiotic conditions as reference sites, plant communities in restored sites will not perfectly match the reference sites. Furthermore, such indices fail when reference sites are lacking or degraded. Hence, there is a need for an alternative approach that evaluates the conservation value of a restored site independently from reference sites. We propose that naturalness indicator values can be an option to measure restoration success. The approach of using naturalness indicator values makes use of the fact that plants are able to indicate environmental parameters, including degradation and regeneration. We compared and measured the restoration success of three well-established methods for grassland restoration (sod transplantation, hay transfer, seeding) with three commonly used indices (diversity, number of target species, similarity to reference sites). The results verified earlier studies and showed that sod transplantation led to the highest restoration success followed by hay transfer and seeding of sitespecific seed mixtures. Further, we used those well-established indices for an evaluation of novel, naturalness-based indices (unweighted and cover-weighted mean naturalness indicator values, the sum of naturalness indicator values). While calculating the means of naturalness indicator values failed to offer conclusive information on restoration success, we could show that the sum of naturalness indicator values was highly correlated with the number of target species and compositional similarity to reference sites. Thus, our case study demonstrated that naturalness indices can be an excellent option to estimate success in grassland restoration.
\end{abstract}

Abbreviations: CWMNN-Cover-weighted mean Naturalness indicator values, DSH-Donor site for hay transfer, DSS-Donor site for sod transplantation, FPFI-Frequency positive fidelity index (Tichý 2005), Simpson-Simpson's Index, SUMNN-Sum of Naturalness indicator values, TGSpN-Number of target species, UWMNN-Unweighted Mean Naturalness indicator values.

\section{Introduction}

Lowland meadows are important habitats for many plant and animal species in Europe (Hájek et al. 2008, Habel et al. 2013). However, hydrological perturbation (i.e., drainage), land use change (intensification or abandonment) and infrastructure-related land consumption have led to a decline of lowland meadow area and occurrence, and have altered the species composition of remaining meadows (Straškrabová and Prach 1998, Poschlod et al. 2005, Tischew et al. 2010, de Snoo et al. 2012).

Within the scope of applied nature conservation, the restoration of lowland meadows has become a major issue during the last two decades. Ecological restoration can be a valuable tool to counteract further decline of this vegetation type, to provide habitat for endangered species and to compensate for land degradation (Conrad and Tischew 2011, Török et al. 2011). The latter is, in fact, rooted in European legislation, i.e., the Habitats Directive (EC 1992) and the Environmental Impact Assessment Directive (EC 2014).
However, in this context one major problem arises: How should the somewhat vague term of restoration success be measured (Bakker et al. 2000, McCoy and Mushinsky 2002, Zedler 2005, Suding 2011)? This is a crucial question rooted in European law, where in fact creation of proper replacement habitats is a prerequisite for permitting projects that trigger a loss of species or habitats, which are, for example, protected by the Habitats Directive (EC 1992, 2014).

Previous studies have used indices that relied on a comparison to reference sites (Ruiz-Jaen and Aide 2005, Sengl et al. 2015, Sengl et al. 2017). For instance, restored and reference sites have been compared with regards to species diversity (Martin et al. 2005, Galvánek and Lepš 2008), the number of predefined target species (Kiehl et al. 2006, Lengyel et al. 2012), the presence or cover of certain functional groups (i.e., perennial grasses, target forbs, weeds: Valkó et al. 2016) and compositional similarity (Fagan et al. 2008, Conrad and Tischew 2011, Valkó et al. 2017). However, if we measure restoration success like this, high restoration success can only be achieved when the restoration sites (a) provide very 
similar habitat conditions as compared to available reference sites and (b) are rather close to the reference sites (White and Walker 1997, Valkó et al. 2017).

Since in practice both biotic and abiotic conditions and the surrounding landscape of the restoration sites can differ significantly from the reference sites, it cannot be assumed that the same vegetation will develop in restored sites (van Diggelen and Marrs 2003). Furthermore, such indices fail when reference sites are lacking or degraded. Considering that there are often limiting factors or constraints in restoration projects concerning site availability, abiotic site conditions or structure at the landscape level (Pfadenhauer 2001, Prach 2007, Suding 2011), there is a need for an alternative index that evaluates the conservation value of a restored site independently from the state of the reference site.

We propose that naturalness indicator values can be an option to measure restoration success. The approach of using naturalness indicator values makes use of the fact that plants are able to indicate several environmental parameters, including degradation (Kowarik 1990, Borhidi 1995). Thus, naturalness represents the reciprocal value of hemeroby (Sukopp 1972, Berg et al. 2014). The concept of naturalness is analogous to the ecological indicator values of Ellenberg et al. (1991), where species receive numerical ordinal values according to their ecological optima along an environmental gradient (e.g., temperature, light availability, etc.). Similarly, each plant species within a region can be assigned to relative naturalness of the habitat according to its observed tolerance against habitat disturbance and degradation. Species with higher values tend to be related to natural or semi-natural habitats, while species with lower values tend to be more frequent in disturbed sites, a relationship that has been statistically verified in some cases (Kowarik 1990, Kim et al. 2002). Though plants with a high naturalness score may occur in disturbed sites by chance, variously degraded habitats in general harbor a characteristic set of indicator species, as shown by several analyses (e.g., Török and Szitár 2010, Cseresnyés et al. 2014). Thus, naturalness indicator values can be used to estimate habitat degradation and regeneration as well. Though it has been proposed to use naturalness indices within ecological restoration (e.g., Machado 2004), this has not yet been applied to assess restoration success.

In this study performed in South Eastern Austria, we evaluated three well-established techniques for lowland meadow restoration: sod transplantation, hay transfer and seeding (Török et al. 2011, Kiehl et al. 2010). Based on a previous study (Sengl et al. 2017) we measured restoration success through several well established indices: diversity, number of target species, similarity to reference sites (Ruiz-Jaen and Aide 2005, Scotton et al. 2012) and compared this result with newly defined indices based on the naturalness indicator values of plants established by Borhidi (1995) for the Pannonian region.

In particular, we asked the following question: Is the naturalness indication approach a valuable alternative to reference sites when assessing restoration success? Based on the findings of Erdős et al. (2017) we assumed that mean naturalness indicator values provide conclusive information on the level of degradation of habitats and thus, would allow us to evaluate restoration success. Additionally, we tried out a new approach by calculating the sum of naturalness indicator values, which ads the factor "diversity" to the index. We assumed that the combination of diversity and naturalness both targets in grassland restoration - would further improve the capability of the index to indicate restoration success.

\section{Methods}

\section{Study area}

The study area was located in alluvial river valleys in South-East Austria, in the vicinity of the communities Fürstenfeld (47 $03^{\prime} \mathrm{N}, 16^{\circ} 04 \mathrm{E}$ ', $280 \mathrm{~m}$ a.s.1.) and Halbenrain $\left(46^{\circ} 43^{\prime} \mathrm{N}, 15^{\circ} 56^{\prime}, 230 \mathrm{~m}\right.$ a.s.1.). The mean annual precipitation in this region is $737-827 \mathrm{~mm}$ and the mean annual temperature is $9.1-9.3^{\circ} \mathrm{C}$ (ZAMG 2016). Soils are non-calcaric alluvial soils and stagnosols (Lebensministerium 2016), with a potential natural vegetation of alluvial lowland forest (Kilian et al. 1994). However, nowadays these river valleys are mostly used for cultivating corn. Reference sites $(\mathrm{N}=8)$ and donor sites for sod transplantation $(\mathrm{N}=1)$ and hay transfer $(\mathrm{N}=7)$, respectively, belonged to the Molinion caeruleae Koch 1926 (alluvial meadows) and had been managed by mowing twice a year. Mean number of vascular plant species was 35.9 on $4 \mathrm{~m} \times 4 \mathrm{~m}$ plots. Restoration sites $(\mathrm{N}=10, \mathrm{~A}=$ 1400-12000 $\mathrm{m}^{2}$ ) encompassed former arable fields on which corn and Styrian oil pumpkin were grown.

\section{Restoration measures}

Restoration measures were carried out in 2012 or 2013 and included:

(1) Sod transplantation: In April, the upper $30 \mathrm{~cm}$ of the soil layer and vegetation cover were cut out with a modified excavator shovel and sod pieces $(1 \mathrm{~m} \times 1 \mathrm{~m}$ size $)$ were then transferred to two receptor sites. The receptor sites encompassed four patches of $15 \mathrm{~m} \times 15 \mathrm{~m}$ and four patches of $10 \mathrm{~m} \times 20$ $\mathrm{m}$, respectively, which were prepared by removing the upper $30 \mathrm{~cm}$ of the topsoil. The distance between the transplanted sod patches was in each case approximately $10 \mathrm{~m}$. For details on species composition of donor sites for sod transplantation (DSS) see Table A1.

(2) Hay transfer: The receptor sites $(\mathrm{N}=4)$ were prepared by ploughing and harrowing. In early summer (end of June), donor sites were mowed, the green hay transferred to the receptor sites and distributed in a ratio of 1-2:1 between donor and receptor site. At receptor sites, hay was distributed manually in a 3-5 cm thick layer. For details on species composition of donor sites for hay transfer (DSH), see Table A1.

(3) Seeding: in May, we applied a seed mixture to receptor sites $(\mathrm{N}=4)$ prepared by ploughing and harrowing. The mixtures consisted of propagules of 22 typical lowland meadow species (Table A2). Seed mixture was of Austrian and German provenance. 
Table 1. Indices of restoration success, calculated for every plot.

\begin{tabular}{|c|c|c|}
\hline Index & Abbreviation & Description \\
\hline Simpson's index & Simpson & $\begin{array}{l}\text { Simpson's diversity index is a measure of } \alpha \text {-diversity which takes into } \\
\text { account both richness and evenness. The index increases either by hav- } \\
\text { ing more species, or by having a greater evenness. }\end{array}$ \\
\hline Number of target species & TGSpN & $\begin{array}{l}\text { Total number of typical lowland meadow species (i.e., diagnostic spe- } \\
\text { cies) according to Ellmauer and Mucina (1993) and Oberdorfer (2001). }\end{array}$ \\
\hline Frequency positive fidelity index & FPFI & $\begin{array}{l}\text { FPFI (Tichý 2005) is a similarity index that considers both frequency } \\
\text { and fidelity of species and thus allows a comparison of single vegetation } \\
\text { plots to vegetation-units. }\end{array}$ \\
\hline Mean naturalness indicator values & UWMNN & $\begin{array}{l}\text { Unweighted mean of naturalness indicator values (Borhidi 1995) of all } \\
\text { species in a plot. }\end{array}$ \\
\hline $\begin{array}{l}\text { Cover-weighted mean naturalness indicator } \\
\text { values }\end{array}$ & CWMNN & $\begin{array}{l}\text { Mean of naturalness indicator values (Borhidi 1995) of all species in a } \\
\text { plot, weighted by cover values (in \%). }\end{array}$ \\
\hline Sum of naturalness indicator values & SUMNN & $\begin{array}{l}\text { Sum of naturalness indicator values of all species (Borhidi 1995) in a } \\
\text { plot. }\end{array}$ \\
\hline
\end{tabular}

After initial treatments, all sites were mowed in late summer of the same year. In the following three years, they were mowed in early and late summer (June and September); the harvested biomass was removed.

\section{Data sampling and preparation}

We surveyed vegetation in $4 \mathrm{~m} \times 4 \mathrm{~m}$ plots, as proposed by Chytrý and Otýpková (2003) for temperate grasslands. We estimated the cover of every vascular plant species with an extended Braun-Blanquet cover-abundance scale (Dengler et al. 2008) and converted the cover scale for further analyses as follows: $\mathrm{n} / \mathrm{a}=0 \%, \mathrm{r}=1 \%,+=2 \%, 1=3 \% ; 2 \mathrm{~m}=4 \%, 2 \mathrm{a}=$ $8 \%, 2 b=18 \%, 3=38 \%, 4=68 \%, 5=88 \%$. Plant nomenclature followed Fischer et al. (2008). We sampled one plot per reference site (total number of plots $=8$ ) and placed plots in the middle of the sites to avoid edge effects. Restoration sites were sampled three years after initial restoration measures were carried out. For each restoration method we sampled eight plots (total number of plots in restoration sites $=$ 24). Full information on vegetation and site data is given in the Electronic Appendix (Table A1). Due to the limited number of sites, we sampled two plots per site in hay transfer and seeding sites, and four plots per site in sod transplantation sites, but we abided a minimum distance of $20 \mathrm{~m}$ between plots to avoid pseudo replicates.

\section{Indices for measuring restoration success}

We evaluated restoration success by calculating six indices for every plot (Table 1): (1) Simpson's index, (2) number of target species (3) similarity to reference sites (frequency positive fidelity index), (4) an unweighted mean of naturalness indicator values, (5) a cover-weighted mean of naturalness indicator values, and (6) a naturalness index calculated by summarizing individual naturalness indicator values. While species richness, diversity and similarity indices are frequently used to measure restoration success, naturalness indicator values (Borhidi 1995) have so far not been used in this context.

We used the Simpson's diversity index for measuring restoration success because it takes into account both speciesrichness and evenness. As species-richness and evenness increase, the Simpson's diversity index (Simpson) increases. Both aspects are considered as targets in ecological restoration of grassland (Martin et al. 2005).

We calculated the number of predefined target species $(\mathrm{TGSpN})$, a frequently used approach in grassland restoration. A species was regarded as target species if it was listed among diagnostic species of lowland meadows in phytosociological standard literature of the study area (see Table A1).

We used frequency positive fidelity index (FPFI) to calculate the similarity between relevés at restored and reference sites because it considers both frequency and fidelity of species and thus allows a comparison of single vegetation relevés to vegetation-units (Tichý 2005). The index ranges from zero (low similarity) to 100 (high similarity).

Naturalness indicators estimate the level of degradation in a plant community. Borhidi (1995) defined naturalness indicator values for the Pannonian flora but a former study has shown that they are suitable for the semi-natural grasslands of South-Eastern Austria (Sengl et al. 2016). The values range from -3 (invasive alien and ruderal species, typical of highly degraded communities) to +6 (specialist species, typical of natural communities).

We calculated the naturalness as species average naturalness indicator values per plot (UWMNN) and as cover-weighted mean naturalness indicator values per plot (CWMNN). Given that these measures have the disadvantage of not taking species richness of a plot into account, we calculated the sum of all naturalness indicator values per plot (SUMNN). In all cases, small or negative values indicate low restoration success (low species numbers and/or high amount of ruderal or alien species), high values indicate high resto- 
ration success (high species numbers and/or high amount of species typical of non-degraded meadows).

\section{Statistical analysis}

We analyzed the effects of different restoration techniques on restoration success indices by first using the Kruskal-Wallis$H$-test to explore overall differences among the treatments and second, a paired Mann-Whitney- $U$-test to explore differences between treatments. We used sequential Bonferroni correction (Holm 1979) to adjust significance due to multiple testing. For

\section{A}

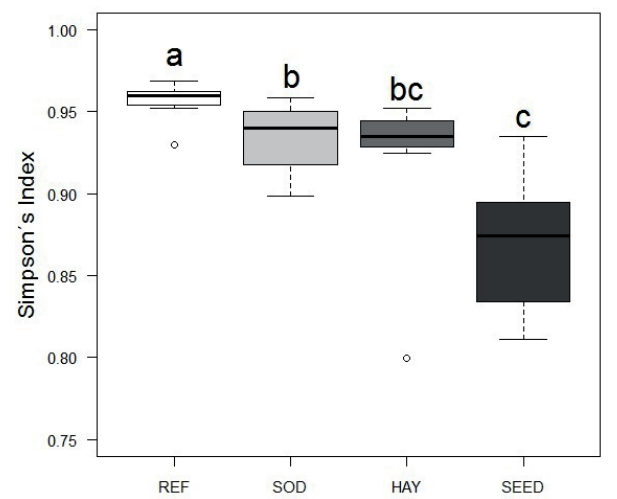

C

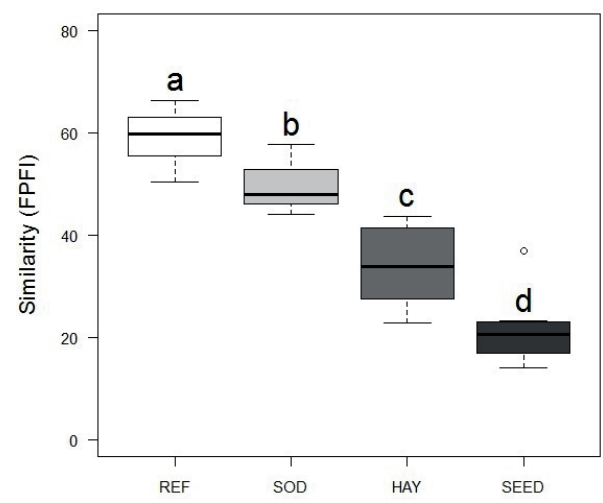

E

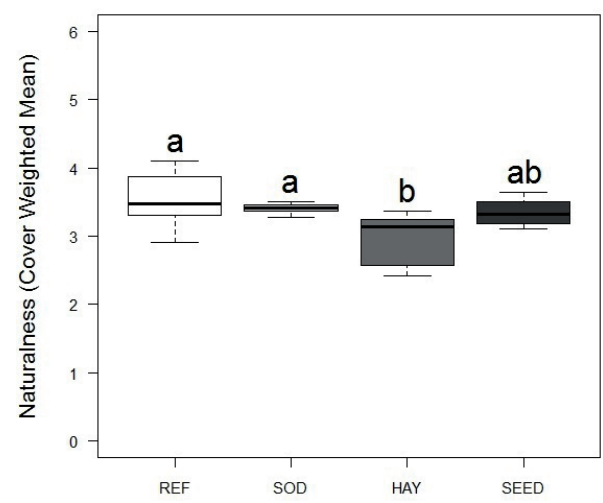

estimating correlations among standard restoration success indices and our naturalness based indices we used a SpearmanRho matrix. All statistical analyses were performed using the software R 3.2.3 (R Core Team 2015).

\section{Results}

All of the established indices (Simpson's index, number of target species and similarity) showed the highest values at the reference sites and the lowest values for sites restored by seeding (Fig. 1, A-C). Sod transplantation and hay transfer

B

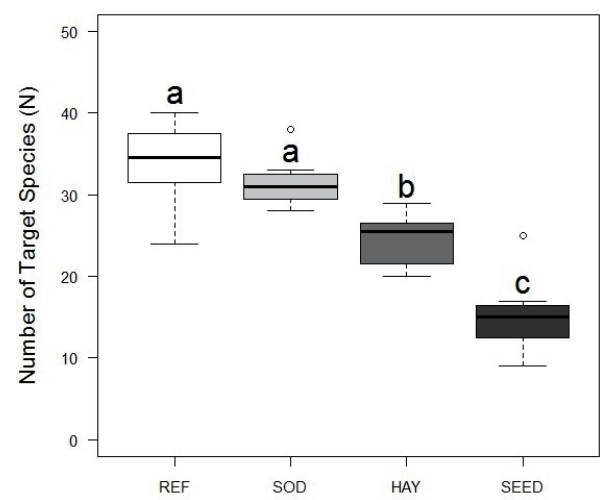

D

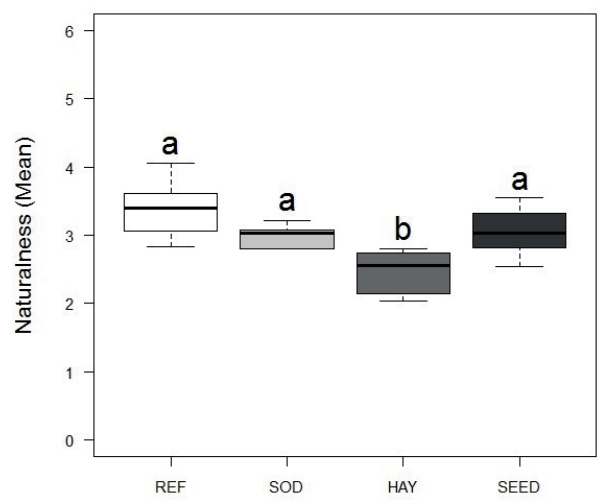

$\mathrm{F}$

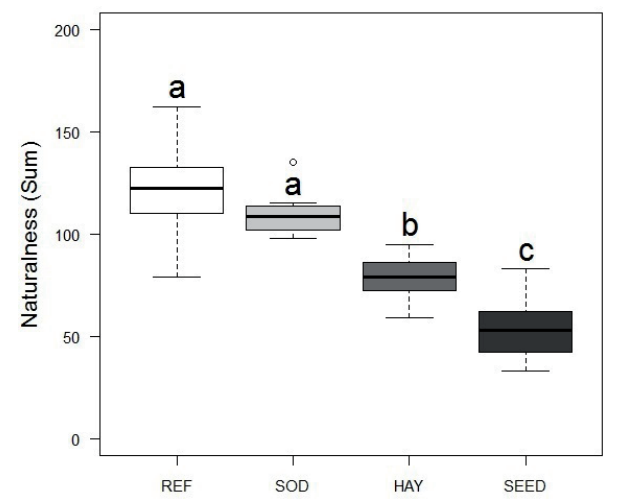

Figure 1. Boxplots of restoration success across restoration methods measured by different indices. Lowercase letters indicate significant pairwise differences between treatments $(\mathrm{P}<0.05$; Kruskal-Wallis- $H$ for overall differences among restoration methods; MannWhitney- $U$ for pairwise comparisons were carried out for every restoration treatment and the value for the reference site). 
did not differ significantly by considering the Simpson's index but regarding the number of target species and similarity, sod transplantation led to higher restoration success.

Both naturalness indices based on plot-wise means, unweighted or weighted by cover, led to a different outcome (Fig. 1, D and E). Mean naturalness indices did not differentiate between reference sites, sod transplantations and sites restored by seeding. Unlike all the established indices, mean naturalness indices showed the lowest values with hay transfer. Only the sums of naturalness indicator values per plot differentiated between restoration measures and reference sites in the same way as compared with the number of target species (Fig. 1, F).

In addition to a visual comparison, we studied how the different indices for measuring restoration success were correlated to each other (Fig. 2). First, we analyzed how the established indices for evaluating restorations success were connected: Values of the number of target species and similarity to reference sites were highly correlated to each other ( $r s=$ $0.95)$ but had a lower correlation coefficient with Simpson's index ( $r s=0.76$ and 0.77 , respectively). Second, we were interested in how naturalness based indices were correlated

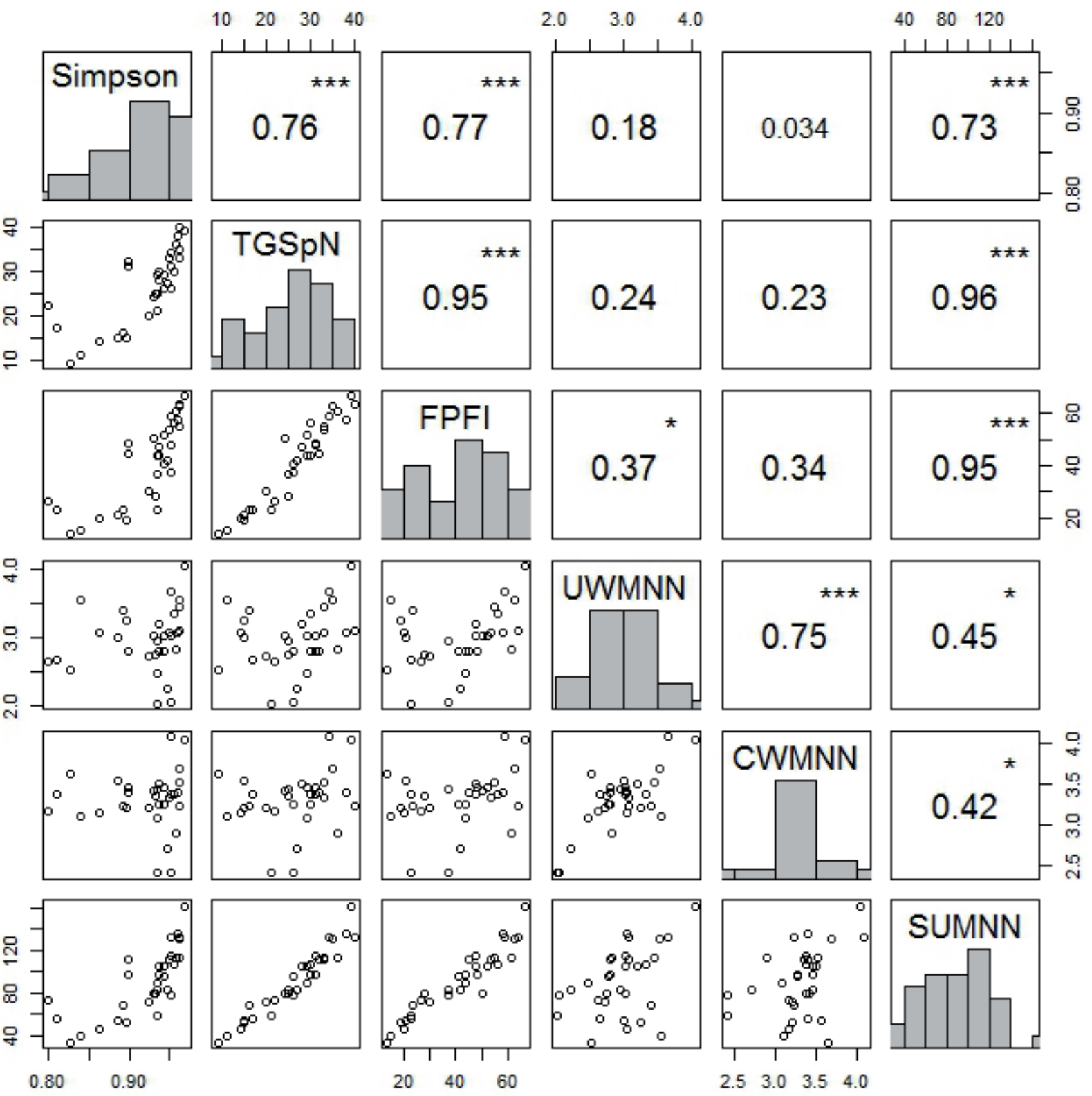

Figure 2. Correlation among indices of restoration success. Numbers indicate Spearman's correlation coefficient $(r s)$. Abbreviations: Simpson = Simpson's diversity index; TGSpN = number of target species; FPFI = similarity measured by the frequency positive fidelity index; UWMNN = unweighted mean naturalness indicator values; $C W M N N=$ cover weighted mean naturalness indicator values; SUMNN $=$ sum of naturalness indicator values. Significance is indicated by asterisks $(*: P<0.05 ; * *: P<0.05 \geq 0.01 ; * * *: P<0.01)$. 
to each other: Unweighted means and cover weighted means were highly correlated to each other $(r s=75)$, but considerably less correlated to naturalness sums ( $r s=0.45$ and 0.42 , respectively). Third, we tried to find out if there were linkages of naturalness based indicator values with the established indices: Unweighted mean naturalness indicator values were significantly correlated to the similarity index $(r s=0.37)$, but displayed no correlation to the Simpson's index and the number of target species. The cover-weighted mean naturalness indicator value was not correlated to any of the established indices for measuring restoration success. Sums of naturalness indicator values showed a high correlation with all established indices for restoration success, but had the highest correlation coefficient with the number of target species $(r s=$ $0.96)$ and with similarity to reference sites $(r s=0.95)$.

\section{Discussion}

The capacity of plants to indicate certain conditions of their environment (i. e. Ellenberg's indicator values) has long been recognized (Diekmann 2003). As plant species differ regarding their tolerances against human impact, they can be used to estimate anthropogenic degradation, or, in contrast a habitat's naturalness (Klotz and Kühn 2002). In this study, we assessed whether Borhidi's (1995) naturalness indicator values are useful to assess restoration success. As an example, we chose some lowland meadows from South-Eastern Austria.

First of all, we have to answer the question why it is valid to use naturalness indices in the framework of restoring seminatural habitats. One may argue that lowland meadows in the study area should not be considered natural (Vrahnakis et al. 2013) because they depend on mowing. Consequently, the application of naturalness indices may seem to be erroneous. However, it is important to recognize that every plant community can be placed on a continuum that stretches between the extremes "artificial" and "natural". Lowland meadows in our study area occupy an intermediate position between croplands and climax forest communities (Dengler et al. 2014). Thus, naturalness is likely to increase when a ploughland is restored and regeneration of a semi-natural grassland proceeds. Accordingly, the application of naturalness indices to estimate restoration success for lowland meadows or other mowing dependent ecosystems seems justified and perfectly in accordance with our current perception of naturalness. In addition, a previous study (Erdős et al. 2017) has shown that naturalness indicators worked very well in differentiating between near natural semi-dry grassland and regenerating grassland in South-East Austria.

In our case study, the well-established indices (i.e., similarity to reference sites and the number of target species) offered valuable and conclusive information on restoration success. The results are in line with a previous study (Sengl et al. 2017), where restoration methods of the same projects were investigated in a three-year chronosequence since restoration start. That study showed that sod transplantation was the most successful restoration method, followed by hay transfer, while seeding of site specific seed mixtures proved to be less effective.

Similarity to reference sites may offer the most valuable information on restoration success. In our case study similarity to reference sites revealed differences across restoration methods most clearly (Fig. 1). However, in many restoration projects reference sites are degraded themselves, or even lacking. In fact, our reference sites were in three cases infected by Solidago canadensis. Also, one of the reference sites was rather species poor (number of species per plot $=26$ ). Additionally, similarity to reference sites may not be a good measure in an early phase of restoration, because grassland restoration in general is a slow process (Fagan et al. 2008, Scotton et al. 2012) and the recreation of natural habitats may take decades (Wilson 2013). So, similarity to reference sites tends to be generally low in this phase and thus unable to differentiate between favorable and unfavorable development.

Likewise, though the number of target species was a good proxy to evaluate restoration success in our case study, underlining the results of similarity to reference sites (Fig. 1 and 2), it may not always be a perfect measure for restoration success because it provides no information on potentially problematic species such as ruderal or invasive species. Also, defining target species is a time consuming process, is only applicable within a limited area, and has to be defined for each habitat type separately (Rosenthal 2003). Additionally, the definition of target species can be a highly subjective process, especially if the definition is based on literature or expert knowledge, when reference sites are absent.

Achieving high diversity is usually one of the primary goals in mesic grassland restoration (Ruiz-Jaen and Aide 2005). Diversity indices can be used without a comparison to reference sites, like naturalness indicator values. However, the Simpson's index failed to differentiate between the three different restoration measures (Fig. 1). This can be explained by the fact that neither component of the Simpson's index (species richness and evenness) considers qualitative species composition. For example, even if sites are invaded by weeds - which is a common problem in the early years after restoration of former cropland (Török et al. 2012) - they can reach a high Simpson's index values because those species also contribute to higher diversity.

Borhidi's naturalness indicator values overcome several of the above-mentioned problems of established indices like availability of a proper reference or lack of qualitative compositional attributes. But, of course, as any other index it has its own inherent problems which have to be dealt with. In theory, naturalness indicator values will only reach high values if a restored site is dominated by species with high individual naturalness values. However, the application of naturalness indicator values led to contradictory outcomes depending on how naturalness indicator values were calculated. While the new SUMNN index provided information on restoration success that was equal to the most meaningful established indices (similarity to reference sites and the number of target species), calculating the mean (both raw and cover-weighted) can lead to a misinterpretation of the processes. The contra- 
dictory outcome can be explained by the fact that Borhidi's naturalness has one disadvantage when used as a measure of restoration success: unlike most other measures applied in this study, it does not take diversity into account. Difficulties may arise when comparing a species-poor and a speciesrich community (Diekmann 2003). Consider the following situation: A site dominantly occupied by one single plant like Phalaris arundinacea, with a typical score for semi-natural grasslands (naturalness value 4) may easily reach a higher mean naturalness than a species-rich grassland dominated by score 4 , but also harboring species with values $<4$. For example, the mean naturalness indicator value of species-rich reference sites in our study was 3.38. Consequently, high naturalness is characterized by a typical combination of different indicator species, not by the absence of some species with low indicator values.

By using sums of naturalness indicator values of a vegetation sample, this problem could be tackled. The pattern of the SUMNN was very similar to the number of target species and similarity to reference sites (Fig. 1). This can also be seen in the correlation analysis, where SUMNN was highly correlated to the number of target species and the FPFI (Fig. 2).

Additionally, the SUMNN index meets several theoretical and practical requirements: As emphasized by Ruiz-Jaen and Aide (2005), at least two variables of ecosystem attributes according to SER (2004) should be used to evaluate restoration success. This can be diversity, the presence of indigenous species, the presence of functional groups necessary for long-term stability and resilience to disturbances. The SUMNN index includes several of these factors (see explanation beforehand). In contrast to several other indices like the saturation index (SI: Klimkowska et al. 2007), the SUMNN index does not rely on the entire species pool of the target communities. This is important if (1) there is no real highvalue target vegetation left in the landscape or (2) restoration sites differ in abiotic conditions (i.e., soil nutrient content, meso-climate, water table) from reference sites (White and Walker 1997). The SUMNN index allows assessing restoration success independent of reference sites (see also McCoy and Mushinsky 2002). Furthermore, several studies have shown that even in the long term and with state-of-the-art techniques, restored grasslands do not reach historical conditions (e.g., Conrad and Tischew 2011, Fagan et al. 2008, Mitchley et al. 2012). Moreover, it is possible that restoration sites develop into an "alternative state" (Alday and Marrs 2013, Suding et al. 2004). This is not unexpected, since reference grasslands have evolved in a long history of continuous development. Consequently, it is valid to question whether the goal for ecological restoration should be a historic reference or a wider context (Hobbs et al. 2009). For the latter, the SUMNN index provides an effective alternative for estimating restoration success.

However, the naturalness indicator values of Borhidi (1995) have so far been defined for the Pannonian Region. It is well-known for ecological indicator values that they vary among biogeographical regions (Diekmann 2003). The same seems likely for naturalness values (Hermy et al. 1999). Though previous studies showed that they work well in
South-Eastern Austria (Sengl et al. 2016, Erdős et al. 2017), it is clear that they need to be adjusted and tested for other biogeographical regions.

Finally, we want to mention that when applying naturalness indices for estimating restoration success, the method should be treated with care, especially if the theoretical basis does not totally match the specific objectives and requirements of a given project. For example, some species with low naturalness values may indicate an efficient restoration progress in some cases (e.g., disturbance tolerant and pioneer species in rock grasslands or open sand surfaces). On the other hand, some species with high naturalness values may not be welcome in other cases (e.g., native trees and shrubs in meadow restoration).

\section{Conclusions}

Naturalness indicator values seemed to be viable estimators for restoration success. By calculating the sum of naturalness indicator values, we combined both naturalness and species richness and created an easy-to-handle index that could replace or complement similarity indices and predefined target species lists to estimate restoration success. Particularly, in cases when reference sites are missing, the sum of naturalness indicator values provides the best alternative to evaluate and monitor restoration success. However, we have to point out that the new index cannot fully substitute a comparison to references sites, provided that these are available. Also, if naturalness indicator values reveal low restoration success, we suggest subsequent analyses of species composition to find out the reason and to provide a base for consecutive management action. Last but not least, several approaches should be used simultaneously to measure restoration success, which can provide complementary information about the vegetation processes. As suggested by our work, the SUMNN index can be one viable approach in some cases.

Acknowledgments. The authors would like to thank P. Ódor and two anonymous referees for helpful comments on earlier drafts of the manuscript. We would also like to thank the BiolArge and the Naturschutzbund Steiermark for providing information on the respective restoration projects and reference sites. Furthermore, we thank S. Weiss (Graz) for his linguistic help. The contribution of L. Erdős was enabled by the Hungarian Eötvös Scholarship of the Hungarian Scholarship Board (grant number 66684).

\section{References}

Alday, J.G. and R.H. Marrs. 2013. A simple test for alternative states in ecological restoration: the use of principal response curves. Appl. Veg. Sci. 17:302-311.

Bakker, J.P, A.P. Grootjans, M. Hermy and P. Poschlod. 2000. How to define targets for ecological restoration? - Introduction. Appl. Veg. Sci. 3:1-72.

Berg, C., A. Abdank, M. Isermann, F. Jansen, T. Timmermann and J. Dengler. 2014. Red Lists and conservation prioritization of 
plant communities - a methodological framework. Appl. Veg. Sci. 17:504-515.

Borhidi, A. 1995. Social behaviour types, the naturalness and relative indicator values of the higher plants in the Hungarian Flora. Acta Bot. Hung. 39:97-181.

Chytrý, M. and Z. Otýpková. 2003. Plot sizes used for phytosociological sampling of European vegetation. J. Veg. Sci. 14:563-570.

Conrad, M.K. and S. Tischew. 2011. Grassland restoration in practice: Do we achieve the targets? A case study from SaxonyAnhalt/Germany. Ecol. Eng. 37:1149-1157.

Cseresnyés, I., E. Cseresnyés-Bózsing, J. Tamás, Z. Barina and P. Csontos. 2014. Effect of Austrian pine on naturalness and succession of vegetation in reclaimed bauxite quarries. Appl. Ecol. Environ. Res. 12:931-946.

Dengler, J., M. Chytrý and J. Ewald. 2008. Phytosociology. In: S.E. Jørgensen and B.D. Fath (eds.) General Ecology Vol. 4 of Encyclopedia of Ecology. Elsevier, Oxford. pp. 2767-2779.

Dengler, J., M. Janišová, P. Török and C. Wellstein. 2014. Biodiversity of Palaearctic grasslands: a synthesis. Agric. Ecosyst. Environ. 182:1-14.

de Snoo, G.R., N. Naus, J. Verhulst, J. van Ruijven and A.P. Schaffers 2012. Long-term changes in plant diversity of grasslands under agricultural and conservation management. Appl. Veg. Sci. 15:299-306.

Diekmann, M. 2003. Species indicator values as an important tool in applied plant ecology - a review. Basic Appl. Ecol. 4:493-506.

Ellenberg, H., H. Weber, R. Düll, V. Wirth, W. Werner and D. Paulißen. 1991. Zeigerwerte von Pflanzen in Mitteleuropa. Scr. Geobot. 18:1-248.

Ellmauer, T. and L. Mucina. 1993. Molinia-Arrhenateretea. In: L. Mucina, G. Grabherr and T. Ellmauer (eds), Die Pflanzengesellschaften Österreichs. Teil 1: Anthropogene Vegetation, Gustav Fischer, Jena, Stuttgart, New York. pp. 297 401.

Erdős, L., Z. Bátori, K. Penksza, A. Dénes, B. Kevey, D. Kevey, M. Magnes, P. Sengl and C. Tölgyesi. 2017. Can naturalness indicator values reveal habitat degradation? A test of four methodological approaches. Pol. J. Ecol. 65:1-13.

European Commission (EC). 1992. Council directive 92/43/EEC of May 1992 on the conservation of natural habitats and of wild fauna and flora. $O . J$. L206:7-50.

European Commission (EC). 2014. Directive 2014/52/EU of the European Parliament and of the Council of 16 April 2014 amending Directive 2011/92EU on the assessment of the effects of certain public and private projects on the environment. $O$. $J$. L124:1-18.

Fagan, K.C., R.F. Pywell, J.M. Bullock and R.H. Marrs. 2008. Do restored calcareous grasslands on former arable fields resemble ancient targets? The effect of time, methods and environment on outcomes. J. Appl. Ecol. 45(4):1293-1303.

Fischer, M.A., K. Oswald and W. Adler. 2008. Exkursionsflora für Österreich, Liechtenstein und Südtirol (3rd ed.). Oberösterreichische Landesmuseen, Linz.

Galvánek, D. and J. Lepš. 2008. Changes of species richness pattern in mountain grasslands: abandonment versus restoration. Biodivers. Conserv. 17:3241-3253.

Habel, J.C., J. Dengler, M. Janišová, P. Török, C. Wellstein and M. Wiezik. 2013. European grassland ecosystems: threatened hotspots of biodiversity. Biodivers. Conserv. 22:2131-2138.

Hájek, M., P. Hájková, D. Sopotlieva, I. Apostolova and N. Velev. 2008. The Balkan wet grassland vegetation: a prerequisite to better understanding of European habitat diversity. Plant. Ecol. 195:197-213.

Hermy, M., O. Honnay, L. Firbank, C. Grashof-Bokdam and J.E. Lawesson. 1999. An ecological comparison between ancient and other forest plant species of Europe, and the implications for forest conservation. Biol. Conserv. 91:9-22.

Hobbs, R.J., E. Higgs and J.A. Harris. 2009. Novel ecosystems: implications for conservation and restoration. Trends Ecol. Evol. 24:599-605.

Holm, S. 1979. A simple sequentially rejective multiple test procedure. Scand. J. Stat. 6:65-70.

Kiehl, K., A. Thormann and J. Pfadenhauer. 2006. Evaluation of initial restoration measures during the restoration of calcareous grasslands on former arable fields. Restor. Ecol. 14:148-156.

Kiehl, K., A. Kirmer, T.W. Donath, L. Rasran and N. Hölzel. 2010. Species introduction in restoration projects - evaluation of different techniques for the establishment of semi-natural grasslands in Central and North-western Europe. Basic Appl. Ecol. 11:285-299

Kilian, W., F. Müller and F. Starlinger. 1994. Die forstlichen Wuchsgebiete Österreichs - Eine Naturraumgliederung nach waldökologischen Gesichtspunkten. Forstliche Bundesversuchsanstalt, Vienna.

Kim, Y.-M., S. Zerbe and I. Kowarik. 2002. Human impact on flora and habitats in Korean rural settlements. Preslia 74:409-419.

Klimkowska, A., R. Van Diggelen, J.P. Bakker and A.P. Grootjans. 2007. Wet meadow restoration in Western Europe: A quantitative assessment of the effectiveness of several techniques. Biol. Conserv. 140:318-328.

Klotz, S. and I. Kühn. 2002. Indikatoren des anthropogenen Einflusses auf die Vegetation. In: BIOLFLOR - Eine Datenbank mit biologisch-ökologischen Merkmalen zur Flora von Deutschland. Schrreihe Veg.kd. 38:241-246.

Kowarik, I. 1990. Some responses of flora and vegetation to urbanization in Central Europe. In: H. Sukopp, S. Hejný and I. Kowarik (eds.) Urban Ecology: Plants and Plant Communities in Urban Environments. SPB Academic, The Hague.

Lebensministerium. 2016. eBod. http://gis.lebensministerium at/eBOD/frames/index.php? \&gui_id=eBOD. Accessed 21 February 2016.

Lengyel, S., K. Varga, B. Kosztyi, L. Lontay, E. Déri, P. Török and B. Tóthmérész. 2012. Grassland restoration to conserve landscapelevel biodiversity: a synthesis of early results from a large-scale project. Appl. Veg. Sci. 15(2):264-276.

Machado, A. 2004. An index of naturalness. J. Nat. Conserv. 12:95110

Martin, L.M., K.A. Moloney and B.J. Wilsey. 2005. An assessment of grassland restoration success using species diversity components. J. Appl. Ecol. 42:327-336.

McCoy, E.D. and H.R. Mushinsky. 2002. Measuring the success of wildlife community restoration. Ecol. Appl. 12:1861-1871.

Mitchley, J., I. Jongepierová and K. Fajmon. 2012. Regional seed mixtures for the re-creation of species-rich meadows in the White Carpathian Mountains: results of a 10-yr experiment. Appl. Veg. Sci. 15:253-263.

Oberdorfer, E. 2001. Pflanzensoziologische Exkursionsflora für Deutschland und angrenzende Gebiete, 8th edn. Eugen Ulmer, Stuttgart.

Pfadenhauer, J. 2001. Some remarks on the socio-cultural background of restoration ecology. Restor. Ecol. 9:220-229.

Poschlod, P., J.P. Bakker and S. Kahmen. 2005. Changing land use and its impact on biodiversity. Basic Appl. Ecol. 6:93-98. 
Prach, K. 2007. Alluvial meadows under changing management: Their degradation and restoration. In: T. Okruszko, E. Maltby, J. Szatylowicz and W. Kotowski. (eds.), Wetlands: Monitoring, Modelling and Management. Taylor \& Francis, London. pp. 265-271.

R Core Team. 2015. R: A language and environment for statistical computing. R Foundation for Statistical Computing, Vienna, Austria. URL: http://www.R-project.org/.

Rosenthal, G. 2003. Selecting target species to evaluate the success of wet grassland restoration. Agric. Ecosyst. Environ. 98: 227-246.

Ruiz-Jaen, M.C. and T.M. Aide. 2005. Restoration success: how is it being measured? Restor. Ecol. 13:569-577.

Scotton, M., P. Golinski, A. Baasch and S. Tischew. 2012. Management options and monitoring of restoration success. In: M. Scotton, A. Kirmer and B. Krautzer. (eds.), Practical Handbook for Seed Harvest and Ecological Restoration of Species-rich Grasslands. Cooperativa Libraria Editrice Universitá di Padova. pp. 59-64.

Sengl, P., M. Magnes, V. Wagner, L. Erdős and C. Berg. 2016. Only large and highly connected semi-dry grasslands achieve plant conservation targets in an agricultural matrix. Tuexenia 36:167190.

Sengl, P., M. Magnes, K. Weitenthaler, V. Wagner, L. Erdős and C. Berg. 2017. Restoration of lowland meadows in Austria: a comparison of five techniques. Basic Appl. Ecol. 24: 19-29.

Sengl, P., V. Wagner and M. Magnes. 2015. Semi-dry grassland restoration in the SE Alpine foreland of Austria - a study of early spontaneous colonisation patterns. Hacquetia 14:97-112.

Society for Ecological Restoration International Science \& Policy Working group (SER). 2004. The SER International Primer on Ecological Restoration. www.ser.org \& Tucson: Society for Ecological Restoration International.

Straškrabová, J. and K. Prach. 1998. Five years of restoration of alluvial meadows: A case study from Central Europe. In: C. Joyce and P. Wade. (eds.), European Wet Grasslands: Biodiversity, Management and Restoration. Wiley, Chichester. pp. 295-303.

Suding, K.N. 2011. Toward an era of restoration in ecology: successes, failures, and opportunities ahead. Ann. Rev. Ecol. Evol. Syst. 42:465-487.

Suding, K.N., K.L. Gross and G.R. Houseman. 2004. Alternative states and positive feedbacks in restoration ecology. Trends Ecol. Evol. 19:46-53.

Sukopp, H. 1972. Wandel von Flora und Vegetation in Mitteleuropa unter dem Einfluß des Menschen. Berichte Landwirtschaft 50: $112-139$.

Tichý, L. 2005. New similarity indices for the assignment of relevés to the vegetation units of an existing phytosociological classification. Plant Ecol. 179:67-72.

Tischew, S., A. Baasch, M.K. Conrad and A. Kirmer. 2010. Evaluating restoration success of frequently implemented compensation measures: results and demands for control procedures. Restor: Ecol. 18:467-480.
Török, K. and K. Szitár. 2010. Long-term changes of rock grassland communities in Hungary. Community Ecol. 11:68-76.

Török, P., E. Vida, B. Deák, S. Lengyel and B. Tóthmérész. 2011. Grassland restoration on former croplands in Europe: an assessment of applicability of techniques and costs. Biodiv. Conserv. 20:2311-2332.

Török, P., T. Miglécz, O. Valkó, A. Kelemen, B. Deák, A. Lengyel and B. Tóthmérész. 2012. Recovery of native grass biodiversity by sowing on former croplands: Is weed suppression a feasible goal for grassland restoration? J. Nature Conserv. 20:41-48.

Valkó, O., B. Deák, P. Török, A. Kelemen, T. Miglécz, K. Tóth and B. Tóthmérész. 2016. Abandonment of croplands: problem or chance for grassland restoration? Case studies from Hungary. Ecosyst. Health Sustain. 2 (2):e01208.

Valkó, O., B. Deák, P. Török, A. Kelemen, T. Miglécz and B. Tóthmérész. 2017. Filling up the gaps-Passive restoration does work on linear landscape elements. Ecol. Eng. 102:501-508.

van Diggelen, R. and R.H. Marrs. 2003. Restoring plant communities - Introduction. Appl. Veg. Sci. 6:106-110.

Vrahnakis, M., M. Janisova, S. Rusina, P. Török, S. Venn and J. Dengler. 2013. The European Dry Grassland Group ( EDGG ): stewarding Europe's most diverse habitat type. In: Baumbach, H. and S. Pfützenreuter (eds.), Steppenlebensräume Europas - Gefährdung, Erhaltungsmaßnahmen und Schutz. Thüringer Ministerium für Landwirtschaft, Forsten, Umwelt und Naturschutz, Erfurt. pp. 417-434.

White, P.S. and J.L. Walker. 1997. Approximating nature's variation: selecting and using reference information in restoration ecology. Restor. Ecol. 5:338-349.

Wilson, J.B. 2013. Biodiversity theory applied to the real world of ecological restoration. Appl. Veg. Sci. 16:5-7.

Zentralanstalt für Meteorologie und Geodynamik (ZAMG). 2016. Klimadaten von Österreich 1981-2010. https://www.zamg.ac.at/ cms/de/klima/informationsportal-klimawandel/daten-download/ klimamittel. Accessed 15 February 2016.

Zedler, J.B. 2005. Success: an unclear, subjective descriptor of restoration outcomes. Ecol. Restor. 25:162-168.

Received May 21, 2017

Revised August 26, 2017 Accepted October 12, 2017

\section{Electronic Appendix}

Table A1. Site conditions and species composition.

Table A2. List of target species, their syntaxonomical affiliation (Ellmauer and Mucina 1993, Oberdorfer 2001) and their proportion in the seed mixtures.

The file may be downloaded from www.akademiai.com. 